\title{
Application of Neural Network in Simple Tool Wear Monitoring and Identification System in MDF Milling
}

\section{Primjena neuronske mreže za jednostavne sustave praćenja i prepoznavanja trošenja alata pri glodanju MDF ploča}

\author{
Preliminary paper • Prethodno priopćenje \\ Received-prispjelo: 28. 6. 2010. \\ Accepted-prihvaćeno: 25. 2. 2011. \\ UDK: $630 * 823.11$ \\ doi:10.5552/drind.2011.1020
}

\begin{abstract}
This paper deals with simple neural network-based diagnostic system, applied to tool wear prediction in MDF milling. Ten tools were used for the test, and each one was consequently worn in the process of MDF milling. During the wearing process, the key process parameters were measured, such as cutting and thrust forces, temperature and power consumption. The neural network-based system was used for tool wear prediction of all the tools except the first one, based on data collected during the previous attempts. The test has shown that the proposed system has good prediction accuracy and that it could be a useful tool in the optimization of the woodworking process.
\end{abstract}

Keywords: tool wear, wood machining monitoring, tool condition diagnostic system

SAŽETAK • U radu se opisuje primjena neuronskih mreža za jednostavan dijagnostički sustav kojim se predviđa trošenje alata pri glodanju MDF (Medium Density Fiberboard) ploča. Za test je uporabljeno deset alata koji su radi istraživanja zatupljivani glodanjem MDF ploča. Tijekom procesa trošenja alata mjereni su temeljni parametri procesa glodanja kao što su sila rezanja i odrivna sila, temperatura i angažirana snaga. Sustav utemeljen na neuronskoj mreži primijenjen je za predviđanje stadija zatupljenosti svih alata osim prvoga, na osnovi podataka dobivenih mjerenjima na prethodnim alatima. Istraživanje je pokazalo da predloženi sustav ima dobru točnost predviđanja i mogao bi biti dobar alat za optimiziranje procesa obrade drva.

Ključne riječi: trošenje alata, praćenje obrade drva, sustav za dijagnostiku stanja alata

\footnotetext{
${ }^{1}$ Author is assistant at Faculty of Wood Technology, Warsaw University of Life Sciences, Warsaw, Poland.

${ }^{1}$ Autor je asistent Fakulteta drvne tehnologije Varšavskog sveučilišta bioloških znanosti, Varšava, Poljska.
} 


\section{INTRODUCTION}

\section{UVOD}

One of the most significant problems of contemporary woodworking is the improvement of the cutting process without sacrificing the quality, which is often degraded by application of blunt or improper tooling. Real-time diagnostic of tool wear should allow more control of the whole machining process by eliminating the production spoilage caused by worn or catastrophically crashed tools. Real-time tool wear and breakage monitoring are based on various measurable factors related to the cutting process, such as cutting and normal forces, machined surface temperature, work power demand and feed mechanisms and acoustic emission related to cutting and material fracture. Key dependencies are presented in Figure 1 (Peklenik and Jerele, 1992)

AI system based on the neural network seems to be the simplest working solution for tool wear prediction. Artificial neural networks allow rejection of regular, time consuming statistical and mathematical analysis. Self learning, trend prediction and generalization properties can replace an experienced machine operator and complex analysis made with traditional methods (Gawlik, 1997).

The objective of this paper is to determine whether AI system based on simple MLP neural network is suitable for identifying tool wear in MDF milling. Industrial methods of predicting tool lifetime based on tool manufacturers' specifications or selfexperience are highly inaccurate (Chryssolouris and Guillot, 1990). The application of AI-based tool wear monitoring system could greatly increase the production efficiency and therefore cause significant economic benefits.

\section{MATERIALS AND METHODS}

\section{MATERIJALI I METODE}

\subsection{Methods}

\subsection{Metode rada}

This paper is aimed at presenting the actual possibility of application of the tool condition monitoring system in milling of wood-based materials. One of the basic assumptions was to enable a comprehensive identification of tool wear without having to stop the machine and without optical or mechanical measurements of any kind. The whole process was to be done by real-time measurement of various factors of the milling process in the period from sharp to blunt cutting tools. The measured factors were as follows:

- Cutting force

- Normal (thrust) force,

- Machined surface temperature,

- Vibration of working spindle,

- Vibration of working table,

- Work unit power consumption,

- Feed unit power consumption.

The basic cutting method is presented in the form of diagram in Figure 2:

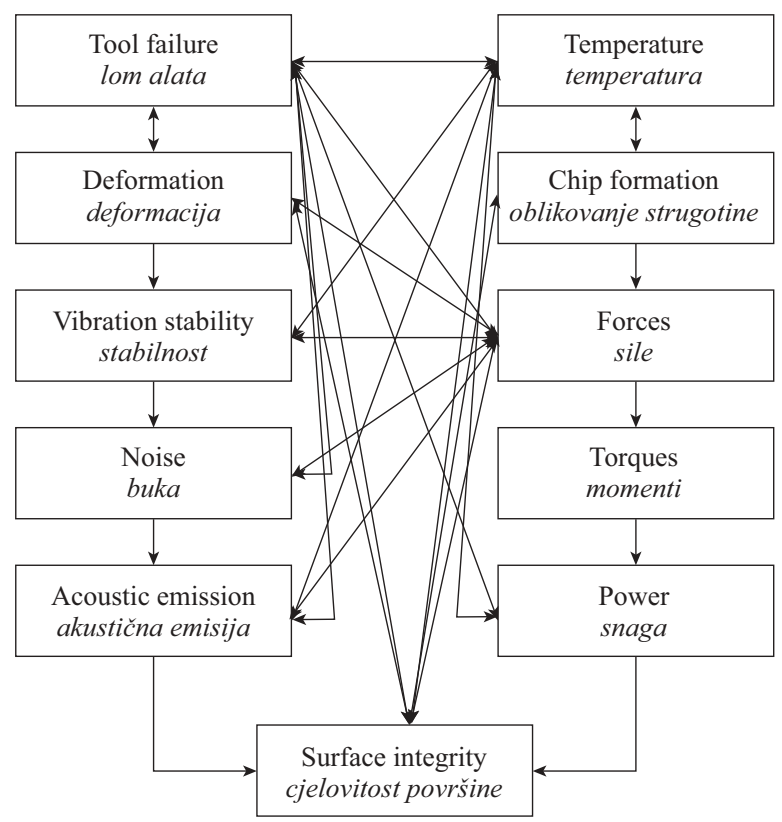

Figure 1 Example of dependencies in a complex cutting process

Slika 1. Shematski prikaz ovisnosti u složenom sustavu rezanja drva

Tool wear parameter was determined as a simple edge recession measured on the rake face (RR), as a parameter simple to measure and linearly conforming to the number of other parameters (McKenzie and Sheikh-Ahmad, 1997; Fisher, 1997).

Tests were performed with standard GP-01 FABA cutterhead equipped with HSS cutters. The number of working head cutters, in laboratory conditions, was limited to 1 , for easier tool wear identification.

Milling parameters were set to values similar to industry standard values in edging of the boards before finishing:

- average chip thickness $g=0.3 \mathrm{~mm}$,

- tool rotational speed $n=3000 \mathrm{rot} / \mathrm{min}$,

- tool diameter $D=160 \mathrm{~mm}$,

- number of working head cutters $z=1$,

- cutting depth $h=4 \mathrm{~mm}$,

- feed speed $u=6.0 \mathrm{~m} / \mathrm{min}$.

\subsection{Experimental stand}

\subsection{Stroj za provedbu eksperimenta}

The test was performed on a special stand designated for diagnostics of the milling process, whose working principle is presented in Figure 4.

The constructed experimental stand is presented in Figure 5.

The experimental stand is based on the "Gomad" FP tenoner, modified with mechanical feed in place of the circular saw module. Three-phase power inverter was used for controlling feed module power workbench with chain-chainwheel mechanism.

The workbench has a measuring platform equipped with XY piezoelectric force sensors. Independently, the tenoner has a laboratory pyrometer for measuring the machine surface temperature. Working spindle and feed motors are connected to a laboratory three- 


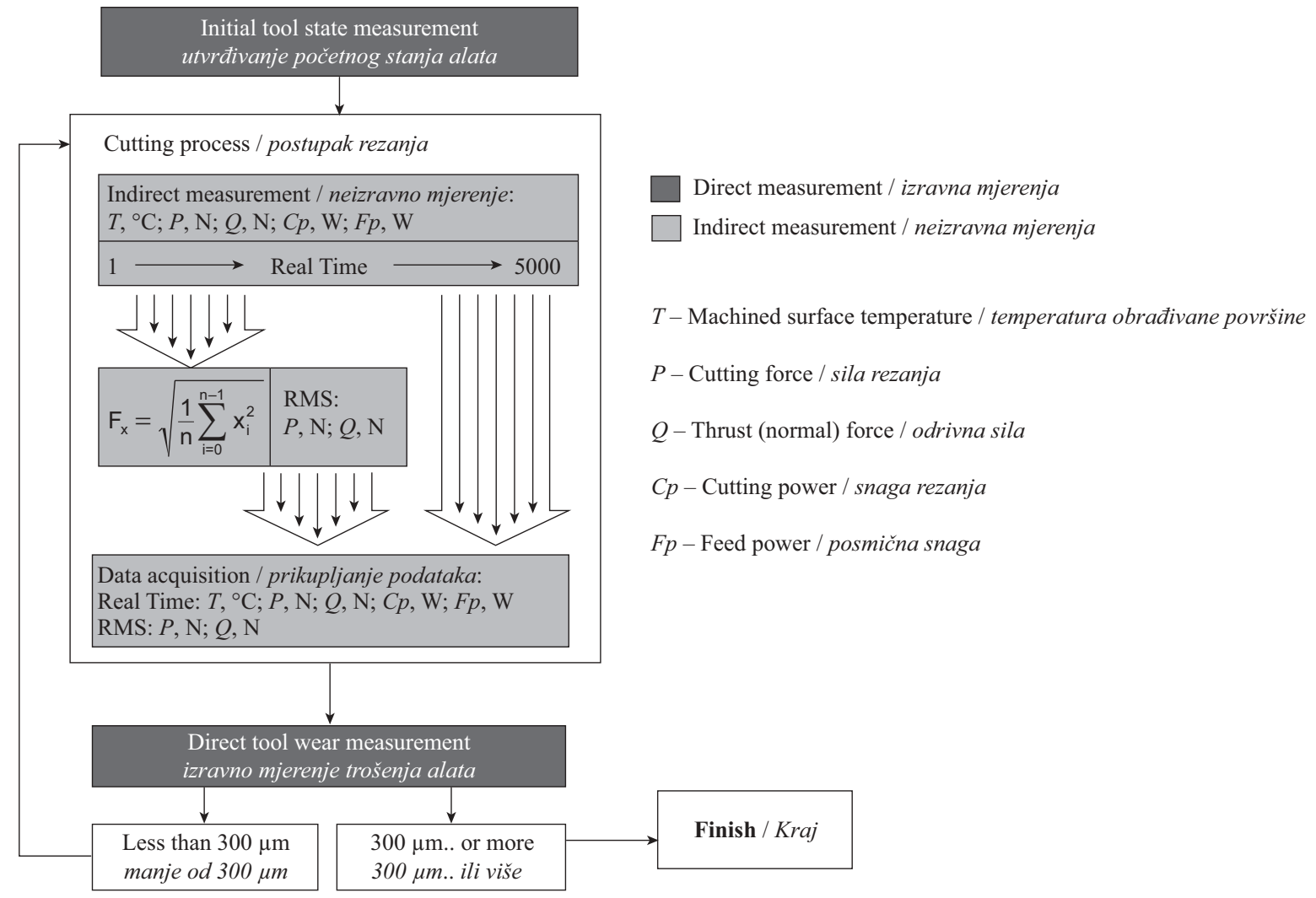

Figure 2 Test method for the assessment of milling

Slika 2. Shematski prikaz metode istraživanja glodanja

phase dual channel wattmeter for measuring the cutting and feed power consumption.

The signals of piezoelectric force sensors, pyrometer and wattmeter are sent through crossover to the amplifier into data acquisition system. Vibration signals were measured with external Bruel\&Kjaer spectrum analyzer.

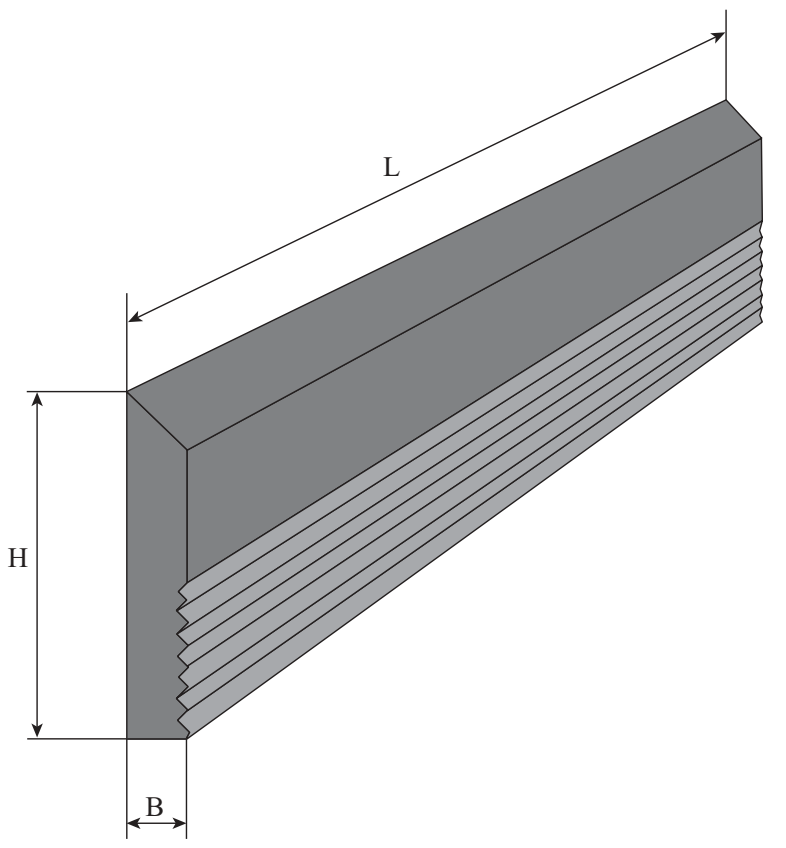

$L=40 \mathrm{~mm}, B=8 \mathrm{~mm}, H=50 \mathrm{~mm}$
The measured values were collected by data acquisition system with the aim of feeding them afterwards into neural network tool wear diagnosis system.

Fig. 6 shows the sample measurement of a $1 / 2$ meter cutting sample machined with sharp tool, and Fig. 7

Figure 3 Cutter used for the test, cutterhead on the tool wear measuring stand

Slika 3. Upotrijebljeni nož za glodanje, glava za glodanje i sustav za mjerenje zatupljenosti oštrice alata 


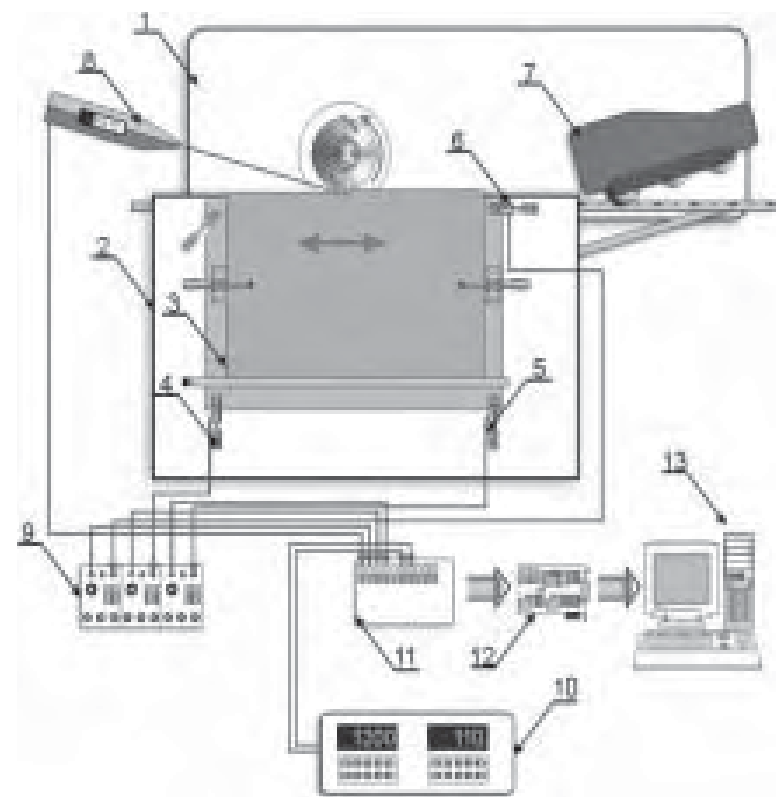

1 - Chassis / postolje

2 - Workbench / radni stol

3 - Workpiece / obradak

4, 5 - Thrust force sensors / senzori za odrivnu silu

6 - Cutting force sensor / senzori za silu rezanja

7 - Feed mechanism / mehanizam za posmično gibanje

8 - Pyrometer / pirometar

9 - Capacitive bridge / charge amplifier / pojačalo

10 - Wattmeter / vatmetar

11 - Crossover / primanje signala

$12-\mathrm{A} / \mathrm{D}$ card / A/D kartica

13 - Data acquisition system / sustav za prikupljanje podataka

Figure 4 Experimental stand diagram

Slika 4. Shematski prikaz provedbe eksperimenta

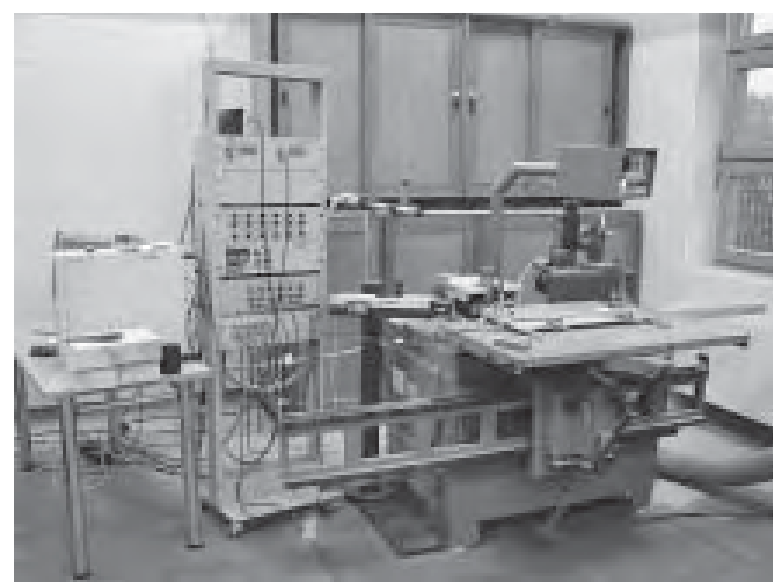

Figure 5 Experimental stand

Slika 5. Stroj na kojemu je proveden eksperiment

shows the measurement with the tool of $300 \mu \mathrm{m}$ edge recession.

All force channels were additionally connected through the module converting the values immediately into root mean square averages.

\subsection{Neural network model \\ 2.3. Model neuronske mreže}

Commercial systems for tool wear identification are based on a single measured parameter, for example working motor power consumption, without AI incorporation ( $\mathrm{Li}, 2001$; Chryssolouris, 1990). This approach, however, can only be used with the well known tool and stable parameters of machined material. Most successful applications use force signals for tool condition monitoring (Byrne, 1995; Sick, 1997; Stein, 1991).

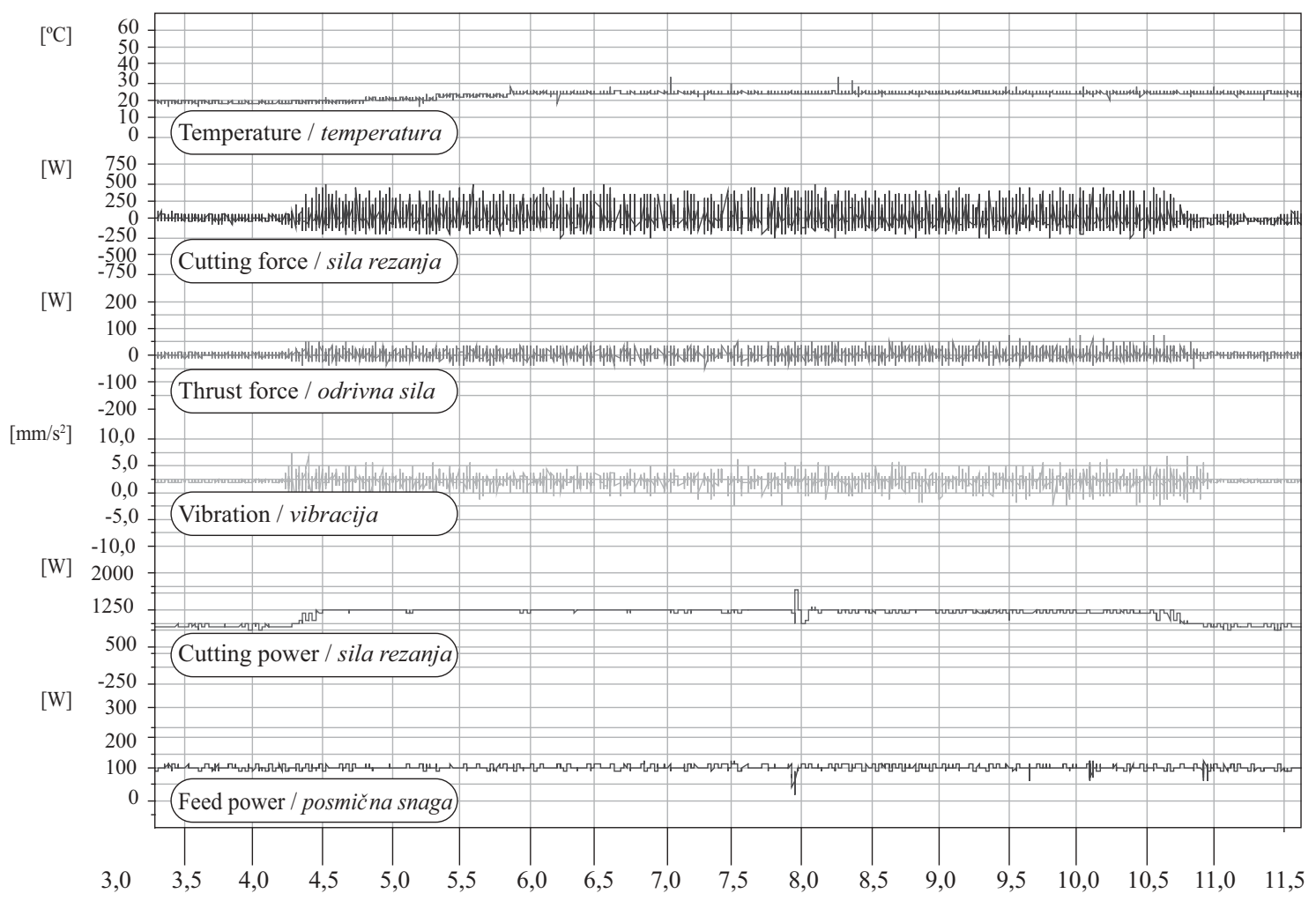

Figure 6 Sample measurement with sharp tool

Slika 6. Primjer mjernih signala za oštri alat 


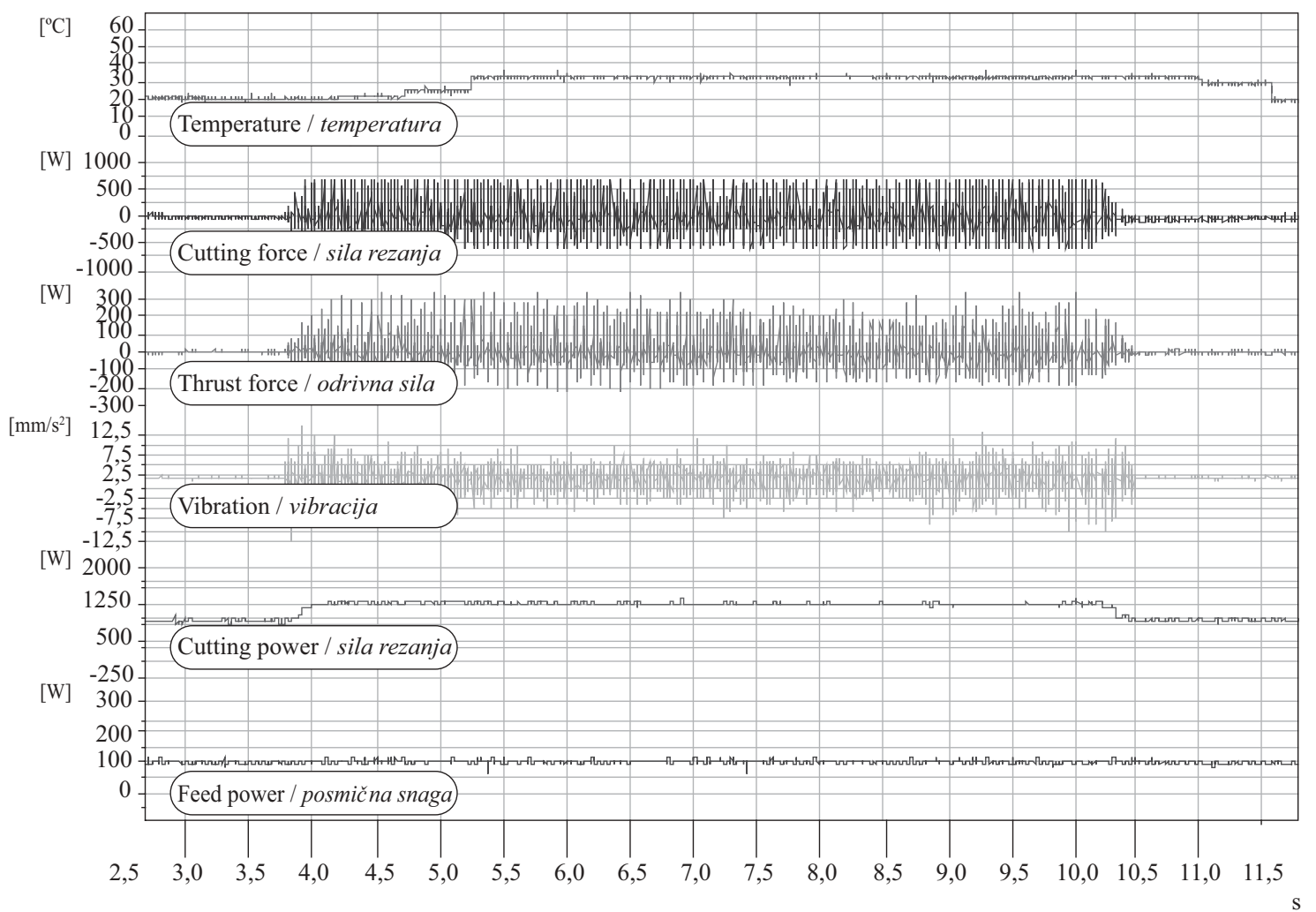

Figure 7 Sample measurement with worn (300 $\mu$ m edge recession) tool

Slika 7. Primjer mjernih signala za zatupljeni alat (zaobljenost oštrice $300 \mu \mathrm{m}$ )

According to literature (Bratkowski, 2001; Teshima, 1993), three-layer neural network is sufficient for the estimation of tool lifetime based on cutting process parameters. Network, however, should be provided with error back propagation algorithm. Some more advanced types as Time Delay Neural Networks may give better results (Sick, 1997; Sick, 1998), but in case of use of pre-processed data, regular MLP could be sufficient. After initial tests, it was observed that in this case an increasing number of neurons in the internal layer axon did not really change overall performance, so the simple model was used. The number of the input layer was based on the tested parameters quantity, and hidden layer neurons were set to four. Network concept is presented in Figure 8.

The presented model was built in Neurodimensions Neurosolutions environment, as a relatively simple Multi Layer Perceptron neural network, additionally equipped with the back propagation algorithm and components increasing learning performance (Tadeusiewicz, 1992-2002). This type of network proved to be successful in monitoring tool conditions in metal machining (Sick, 1997).

The meaning of numbers in Figure 9 is as follows:

1- File component reading data from the computer file system or a data stream.

2- Axon performing an identity map between its input and output activity.

3- Axon used for back propagation of data

4- Step component trying to find the bottom of a performance surface by taking steps in the direction estimated by the attached backprop component.

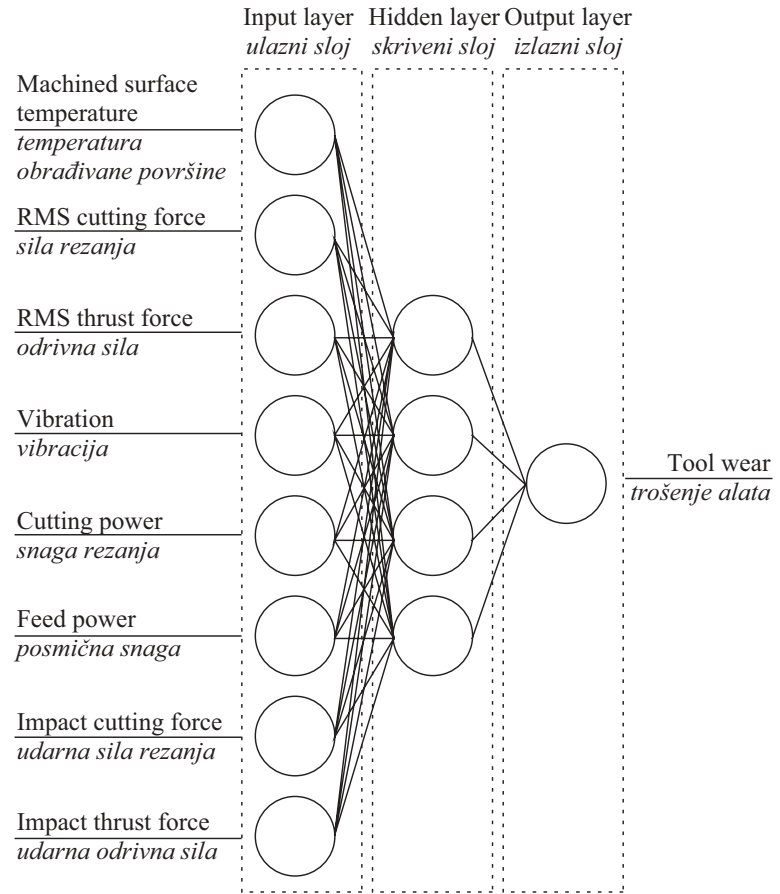

Figure 8 Concept of the neural network model Slika 8. Koncept modela neuronske mreže

The Momentum provides the gradient descent with some inertia, so that it tends to move along a direction that is the average estimate for down.

5- TanhAxon applying a bias and tanh function to each neuron in the layer. This will squash the range of each neuron in the layer to between -1 and 1 . Such nonlinear elements provide a network with the ability to make soft decisions. 


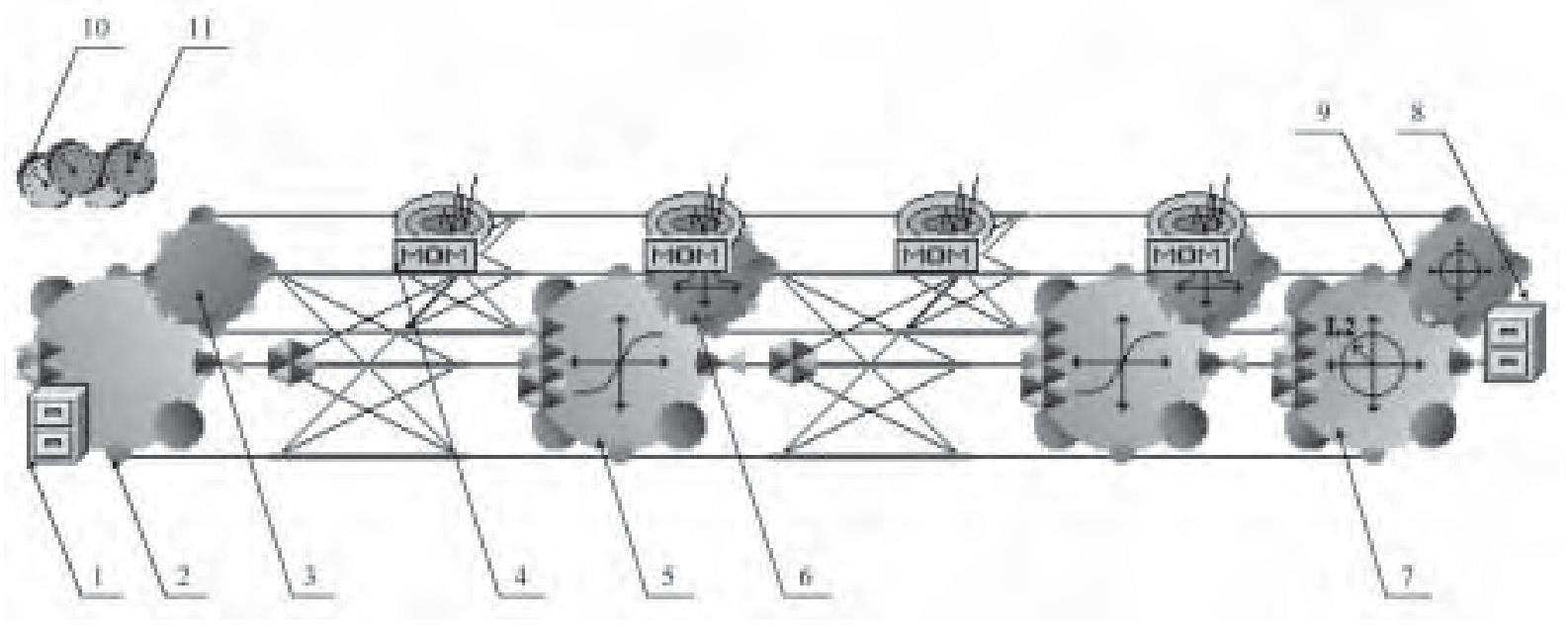

Figure 9 Neural network-based diagnostic system

Slika 9. Dijagnostički sustav utemeljen na neuronskoj mreži

6- Back Linear Axon used for back propagation of data.

7- L2 Criterion implementing the quadratic cost function. The error reported to the supervised learning procedure is simply the squared Euclidean distance between the network output and the desired response.

8- File component writing data to the computer file system or a data stream.

9- BackCriteriaControl stacking on top of any member of the ErrorCriteria family, and communicating with the Backprop components to perform back propagation.

10, 11 - BackStaticControl component used in conjunction with the StaticControl component. Static back propagation assumes that the output of a network is strictly a function of its present input, the gradients and sensitivities are only dependent on the error and activations from the current time step.

In fact, the suggested multi-layer perceptron, being one of the simplest solutions, seemed to be quite sufficient for the averaged data. Extra possibilities provided by time delay neural networks that achieve high accuracy in fast changing processes would not improve the results of the average data. The number of neurons in the input layer was set in accordance with the num- ber of tested factors -8 . The internal layer consisted of only 4 neurons so as to simplify the model. Introductory tests on layers consisting of more neurons failed to show any visible improvement, but extended the learning time.

The network was trained with randomly picked data (supervised training with batch weight updates consisting of 1000 epochs). Training time took from 2 to 10 seconds depending on the amount of input data.

\subsection{Neural network tests}

\subsection{Testiranje neuronske mreže}

As mentioned above, neural network training was made in 1000 epochs randomly chosen from the previously obtained data. 10 tools were used in MDF milling (M1 to M10), and the whole idea was to test the network with a cascade method. M2 tool was tested against network trained with M1 tool data, M3 tool was tested with network fed with M1 and M2 tool data, and so forth, up to M10 tool tested with network trained with M1 to M9 data. Figures show sample dependence of number of epoch on mean square error of neural network training for M2 and M10 test

After training each sample from M2 to M10, the network was tested for accuracy on training data set. In

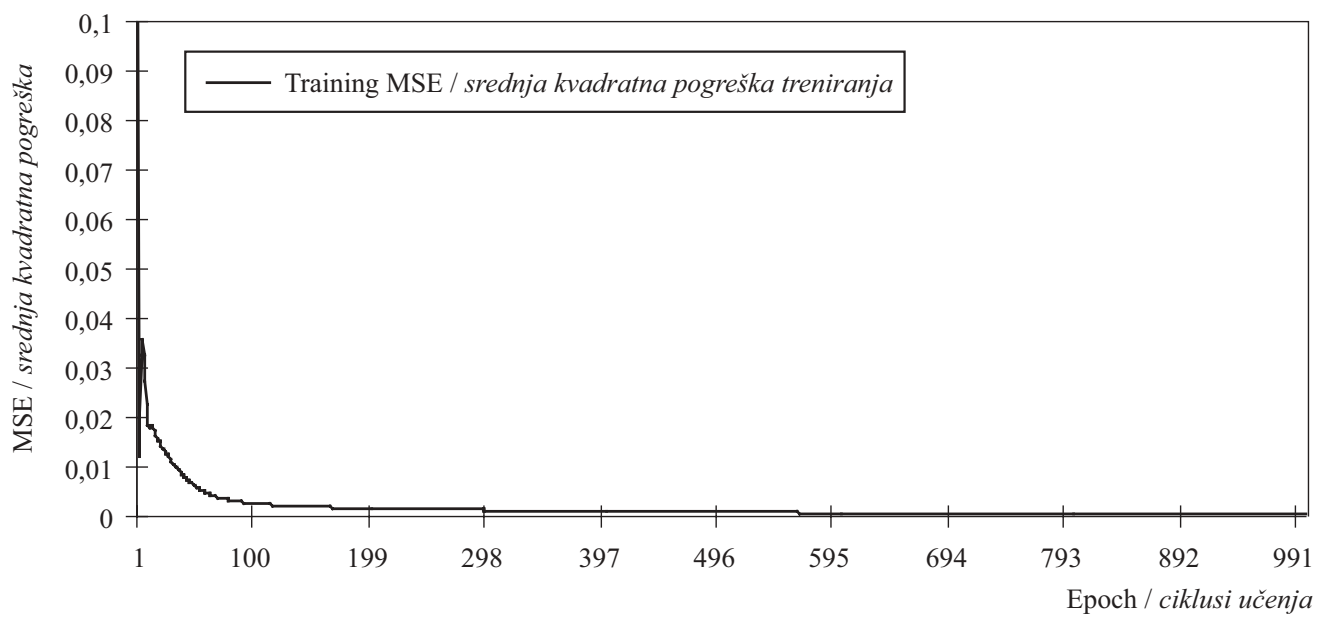

Figure 10 Dependence of mean squared error (MSE) of neural network training for M2 test on number of epochs Slika 10. Ovisnost srednje kvadratne pogreške (MSE) treniranja neuronske mreže za test M2 o broju ciklusa učenja 
Table 1 M2 training MSE

Tablica 1. Srednja kvadratna pogreška treniranja mreže za M2 test

\begin{tabular}{|l|c|}
\hline Supervised Network Training Results / Rezultati treniranja mreže & 1000 \\
\hline Epoch number / Broj ciklusa učenja & 0.000416252 \\
\hline Minimum Mean Squared Error / Minimum srednje kvadratne pogreške & 0.000416252 \\
\hline Final Mean Squared Error / Konačna vrijednost srednje kvadratne pogreške &
\end{tabular}

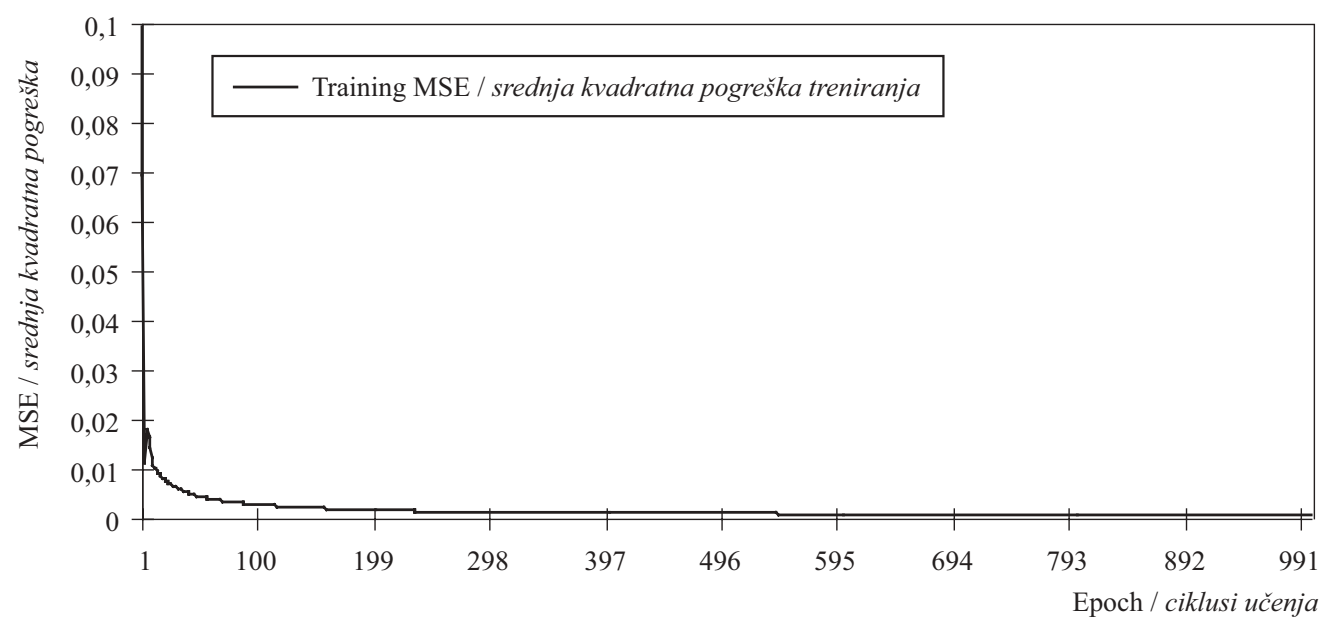

Figure 11 Dependence of mean squared error (MSE) of neural network training for M10 test on number of epochs Slika 11. Ovisnost srednje kvadratne pogreške (MSE) treniranja neuronske mreže za test M10 o broju ciklusa učenja

Table 2 M10 training MSE

Tablica 2. Srednja kvadratna pogreška treniranja mreže za M10 test

\begin{tabular}{|l|c|}
\hline Supervised Network Training Results / Rezultati treniranja mreže & 1000 \\
\hline Epoch number / Broj ciklusa učenja & 0.001148881 \\
\hline Minimum Mean Squared Error / Minimum srednje kvadratne pogreške & 0.001148881 \\
\hline Final Mean Squared Error / Konačna vrijednost srednje kvadratne pogreške & \\
\hline
\end{tabular}

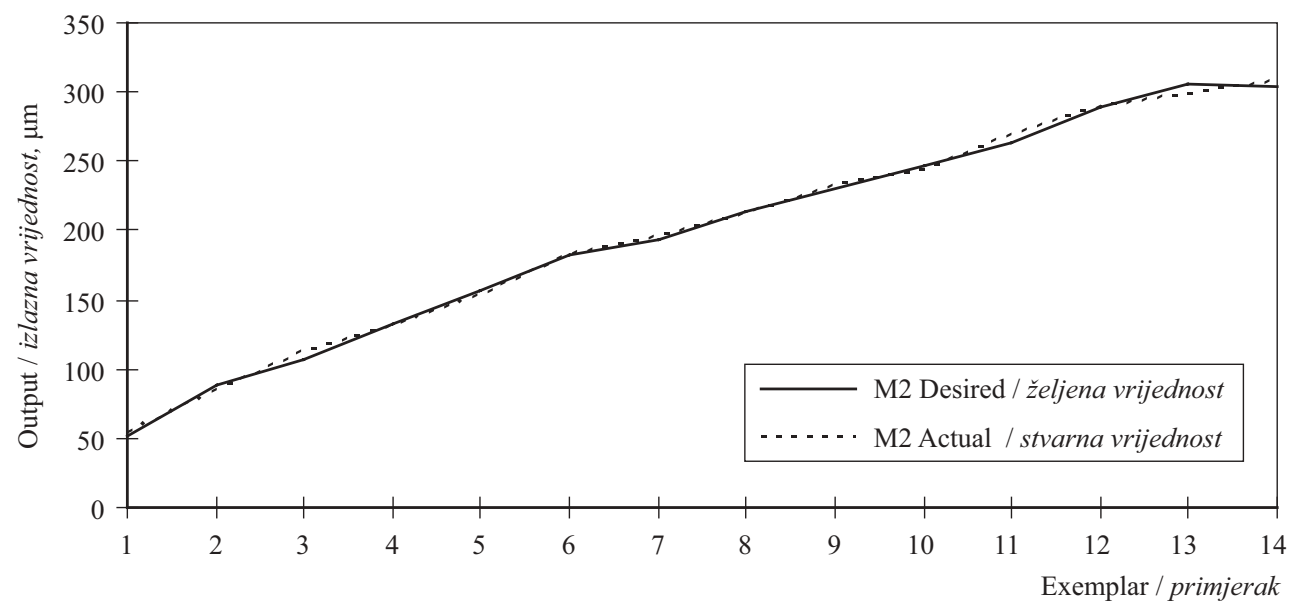

Figure 12 M2 Desired and actual neural network output

Slika 12. Očekivani i stvarni rezultat neuronske mreže za M2 test

Table 3 M2 neural network performance

Tablica 3. Rezultat neuronske mreže za M2 test

\begin{tabular}{|l|c|}
\hline Performance / Rezultat & M2 tool wear / Trošenje alata M2 \\
\hline Mean Squared Error / Srednja kvadratna pogreška & 16.69577584 \\
\hline $\begin{array}{l}\text { Normalized Mean Squared Error/Variance of desired output } \\
\text { Normalizirana srednja kvadratna pogreška / varijanca očekivanog rezultata }\end{array}$ & 0.002669916 \\
\hline Mean Absolute Error / Srednja apsolutna pogreška & 3.503420055 \\
\hline Minimum Absolute Error / Minimalna apsolutna pogreška & 0.056479288 \\
\hline Maximum Absolute Error / Maksimalna apsolutna pogreška & 7.824272765 \\
\hline Linear Correlation Coefficient / Koeficijent linearne korelacije & 0.998675442 \\
\hline
\end{tabular}




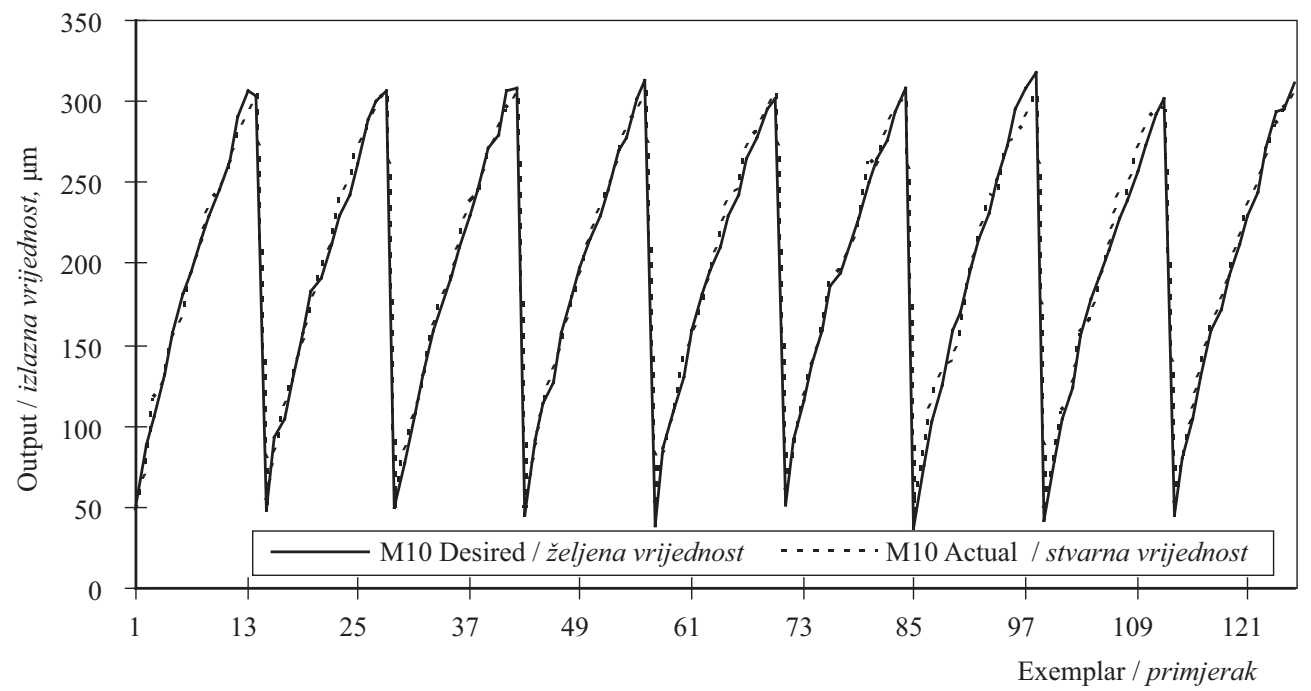

Figure 13 M10 Desired and actual neural network output

Slika 13. Očekivani i stvarni rezultat neuronske mreže za M10 test

Table 4 M10 neural network performance

Tablica 4. Rezultat neuronske mreže za M10 test

\begin{tabular}{|l|c|}
\hline Performance / Rezultat & M10 tool wear / Trošenje alata M10 \\
\hline Mean Squared Error / Srednja kvadratna pogreška & 55.98576686 \\
\hline $\begin{array}{l}\text { Normalized Mean Squared Error/Variance of desired output } \\
\text { Normalizirana Srednja kvadratna pogreška / varijanca očekivanog rezultata }\end{array}$ & 0.008776864 \\
\hline Mean Absolute Error / Srednja apsolutna pogreška & 6.084597287 \\
\hline Minimum Absolute Error / Minimalna apsolutna pogreška & 0.17155033 \\
\hline Maximum Absolute Error / Maksimalna apsolutna pogreška & 19.33887329 \\
\hline Linear Correlation Coefficient / Koeficijent linearne korelacije & 0.995628933 \\
\hline
\end{tabular}

fact the dependence on the amount of training data is not clearly visible, and Figure 12 and 13 show the dependence of the desired and actual network output for every randomly picked testing exemplar.

After being tested against regression and error values, the model has undergone testing against sensitivity about the mean. This means the knowledge of the effect that each network input has on the network output. The procedure provides feedback as to which input channels are the most significant. Obviously, at this stage insignificant channels can be simply removed, reducing the size of the network, and consequently also the training time complexity. The results are shown in Figure 14 and 15.

\section{RESULTS AND DISCUSSION} 3. REZULTATI I RASPRAVA

Tools used for MDF milling were marked with M1-M10 symbols. Diagnostic tests were performed in

M2 Sensitivity About the Mean / Osjetljivost očekivane vrijednosti za M2 test

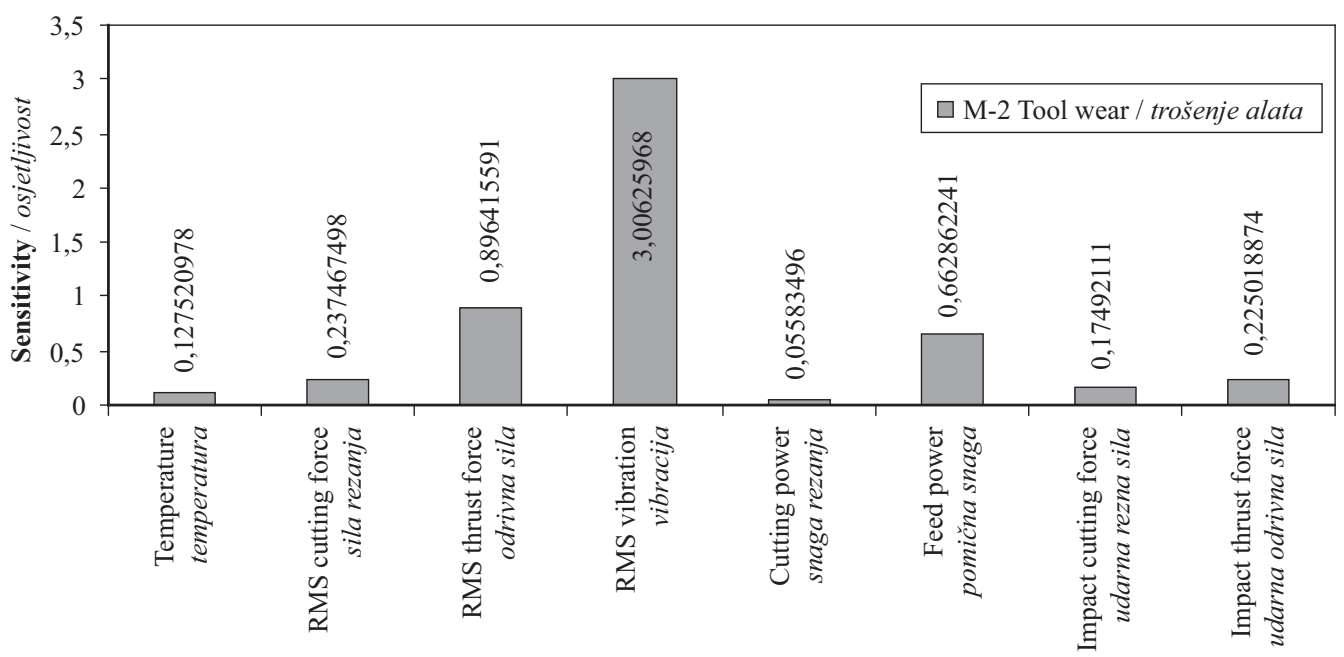

Figure 14 Sensitivity of the M2 tool wear identification network

Input / ulazna vrijednost Slika 14. Osjetljivost mreže za prepoznavanje trošenja alata M2 
M10 Sensitivity About the Mean / Osjetljivost očekivane vrijednosti za M10 test

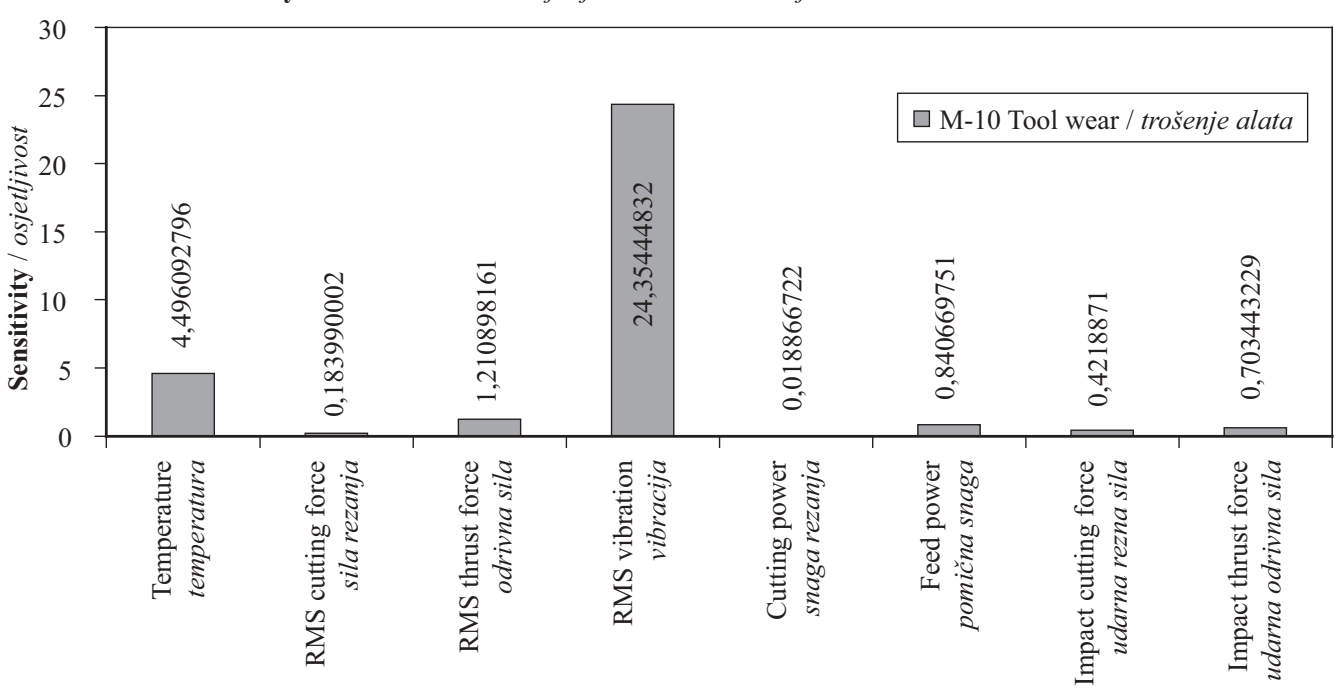

Figure 15 Sensitivity of the M10 tool wear identification network

Input / ulazna vrijednost Slika 15. Osjetljivost mreže za prepoznavanje trošenja alata M10

the following way: data obtained from wear process of M1 tool was fed into neural network, and on this basis M2 tool wear prediction was calculated. After that M1 and M2 tool data were fed into the diagnostic system, and after learning, M3 tool wear was predicted. And so forth, the experiment ended with M1-M9 tools data designated as a learning material, with M10 tool used for wear prediction. Due to space shortage, not all diagrams and result tables are presented, as they are very similar, so it was decided to visually present only half of the results, M2, M4, M6, M8 and M10 tool prediction, leaving M3, M5, M7, M9 aside.

Diagnostic data collected at previous points were used for the preparation of the average diagnostic error in dependence of the number of trials used for training of neural network-based diagnostic system. Obviously the best results $(2.95 \%$ error) were gained with 9 data sets provided as a training set for neural network. After providing only one data set for training identification, accuracy reaches $4.16 \%$. The worst results were recorded with M7 tool predicted on the basis of M1-M6 tools (9.50\% error). The average diagnostic error was defined as a simple average percentage difference between the desired (measured) and actual (neural network predicted) values. Correlation and $\mathrm{R}^{2}$ were calculated between whole groups of the desired and actual output values. Even such accuracy can be recognized as very high in comparison to methods used in wood industry, based only on working time, not taking into account any other indirect factors. Table 5 shows the summary of prediction results with the average diagnostic error and correlation of predicted and measured data sets.

It should be noted that the largest individual diagnostic errors, values up to $20 \%$, were observed in initial

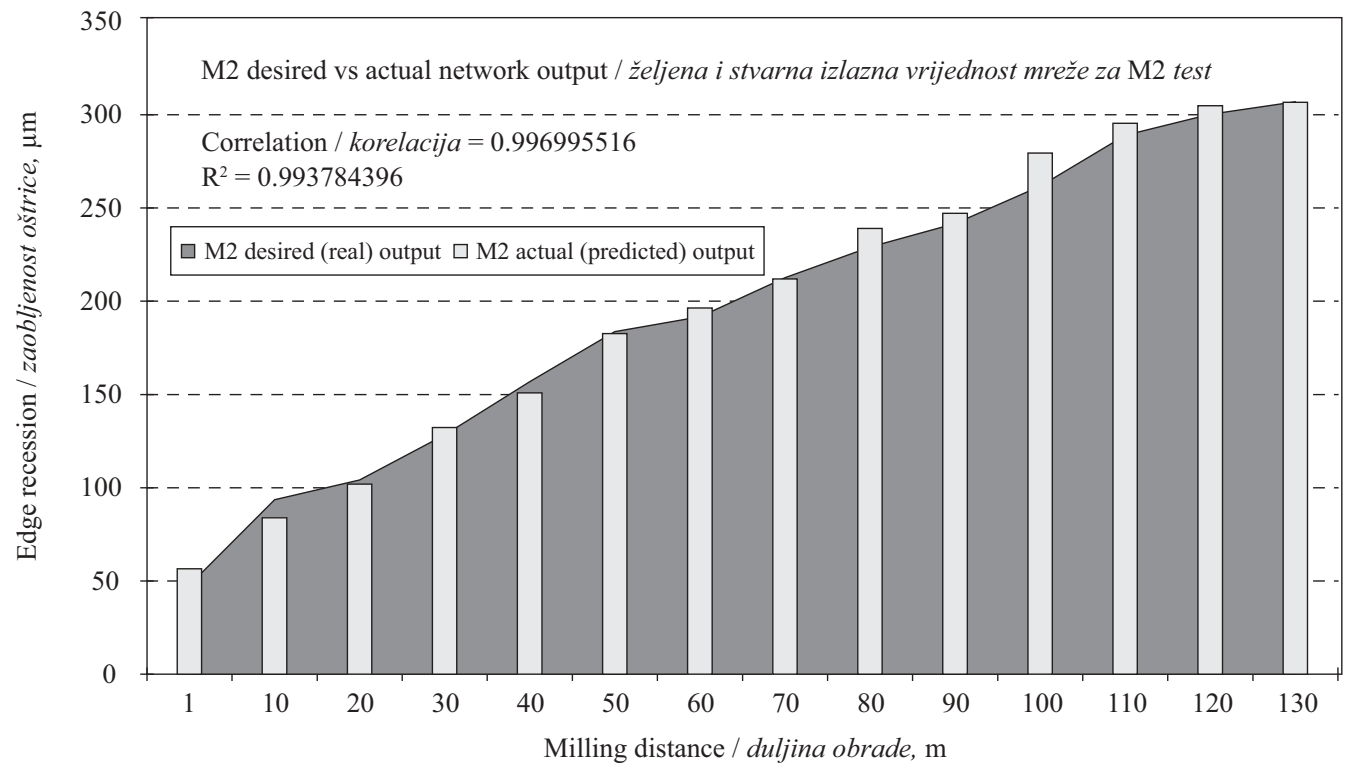

Figure $16 \mathrm{M} 2$ tool wear diagnosis test

Slika 16. Rezultati predviđanja zatupljenosti alata M2 


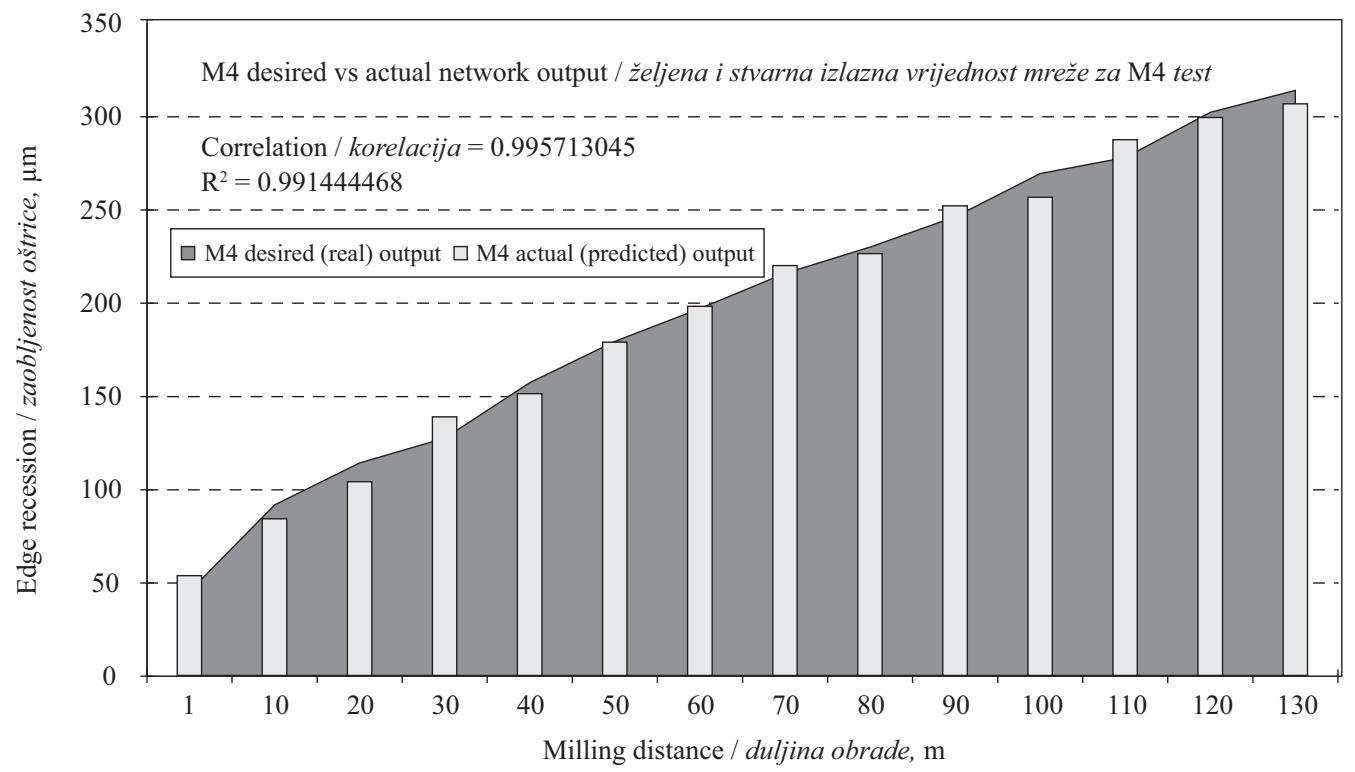

Figure 17 M4 tool wear diagnosis test

Slika 17. Rezultati predviđanja zatupljenosti alata M4

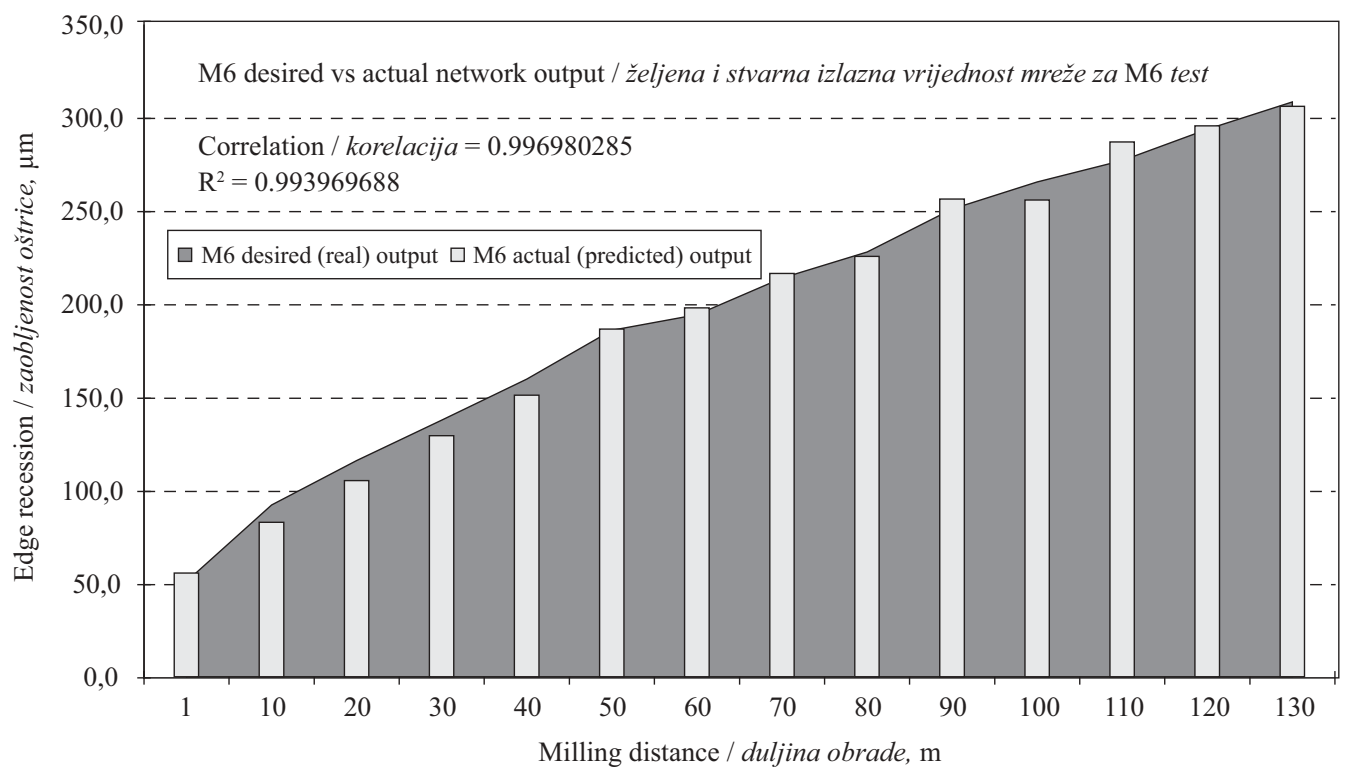

Figure 18 M6 tool wear diagnosis test

Slika 18. Rezultati predviđanja zatupljenosti alata M6

Table 5 Summary of average diagnostic error for M2-M10 tools

Tablica 5. Zbirni podaci prosječne dijagnostičke pogreške za alate M2 - M10

\begin{tabular}{|c|c|c|c|c|}
\hline $\begin{array}{c}\text { Test number } \\
\text { Oznaka testa }\end{array}$ & $\begin{array}{c}\text { Number of tools } \\
\text { used as training data } \\
\text { Broj alata čiji su } \\
\text { podaci uzeti za } \\
\text { treniranje }\end{array}$ & $\begin{array}{c}\text { Average diagnostic } \\
\text { error } \\
\text { Prosječna dijagno- } \\
\text { stička pogreška } \\
\text { \% }\end{array}$ & $\begin{array}{c}\text { Correlation of desired (measured) and } \\
\text { actual (network output) tool wear data } \\
\text { Korelacija izmedu očekivanih } \text { i dobivenih } \\
\text { podataka o zatupljenosti alata }\end{array}$ & $\begin{array}{c}\text { Coefficient of } \\
\text { determination } \\
\text { Koeficijent } \\
\text { determinacije }\end{array}$ \\
\hline M2 & 1 & 4.16 & 0.996995516 & 0.993784396 \\
\hline M3 & 2 & 4.48 & 0.996003252 & 0.990748441 \\
\hline M4 & 3 & 4.72 & 0.995713045 & 0.992022477 \\
\hline M5 & 4 & 5.10 & 0.996706367 & 0.993423583 \\
\hline M6 & 5 & 3.91 & 0.996980285 & 0.993969688 \\
\hline M7 & 6 & 9.50 & 0.994839892 & 0.989706411 \\
\hline M8 & 7 & 6.63 & 0.995698324 & 0.991415153 \\
\hline M9 & 8 & 3.19 & 0.998728859 & 0.997459333 \\
\hline M10 & 9 & 2.95 & 0.998007188 & 0.996018347 \\
\hline
\end{tabular}




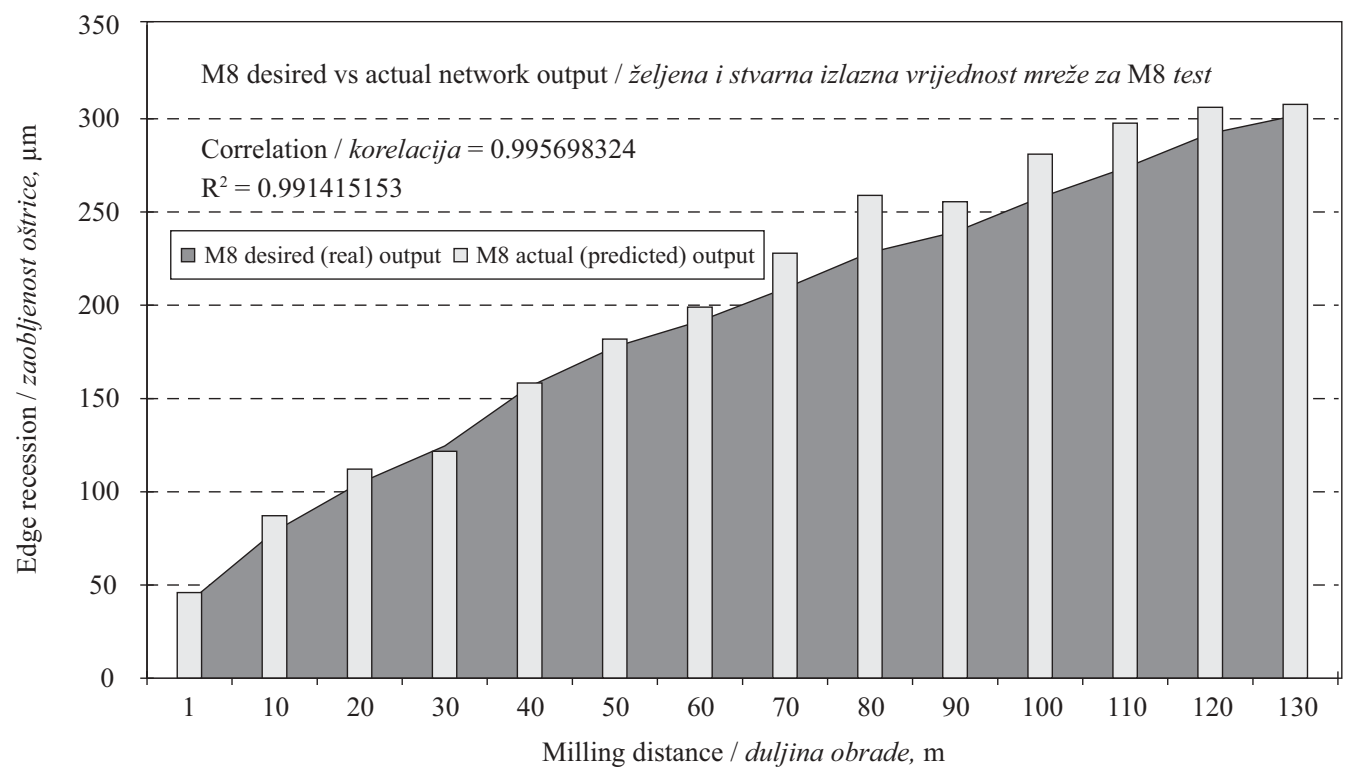

Figure 19 M8 tool wear diagnosis test

Slika 19. Rezultati predviđanja zatupljenosti alata M8

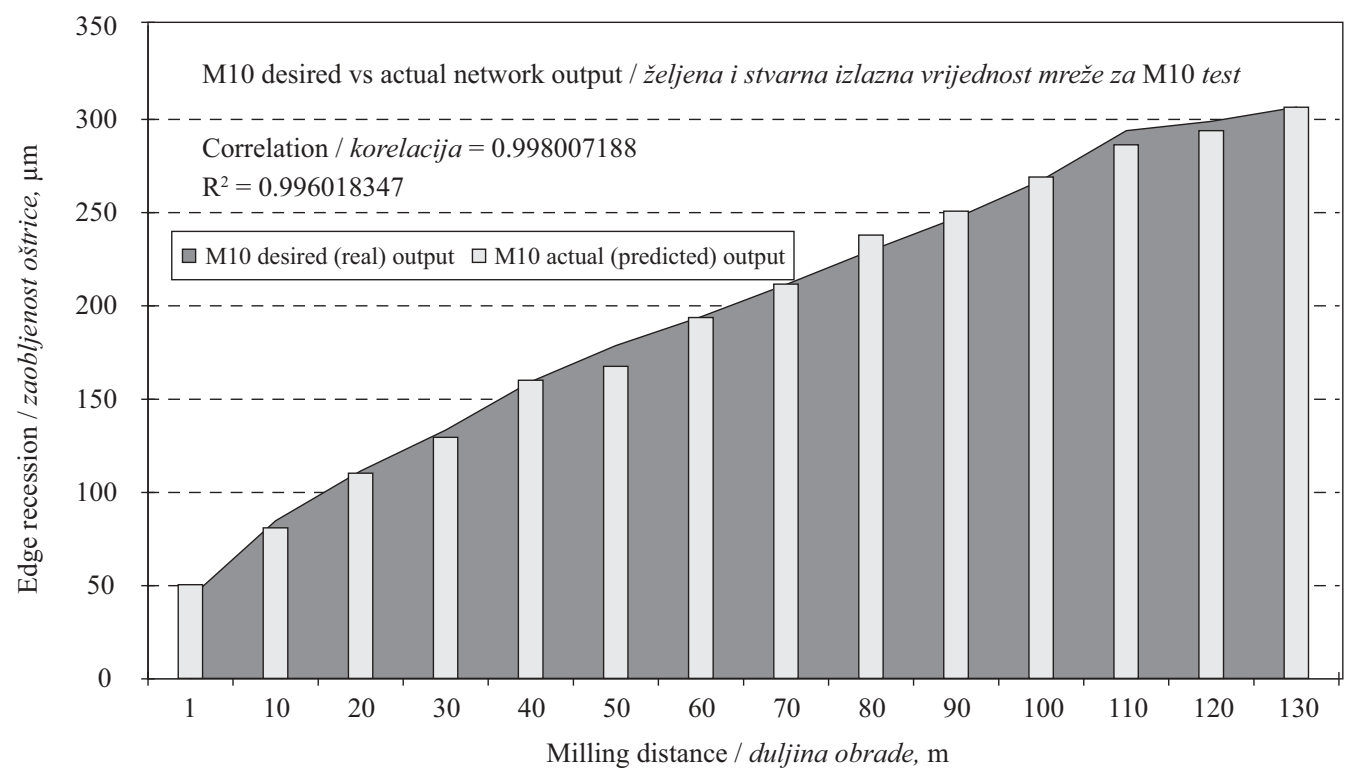

Figure 20 M10 tool wear diagnosis test

Slika 20. Rezultati predviđanja zatupljenosti alata M10

wearing ranging between $50-100 \mu \mathrm{m}$ of the measured edge recession. This can be explained by assuming that the initial wear reaching several micrometers is actually comparable with tool grinding traces. This is quite normal in industry practice. Correlation between the obtained and predicted data in MDF milling in all cases is close to one, reaching 0.9956 in the worst case.

\section{CONCLUSION}

\section{ZAKLJUČCI}

The average diagnostic error of the neural network-based system shows high possibilities of wear identification, when based on indirectly measured data. Errors in comparison to traditionally used methods ba- sed only on work time are in fact negligible. Accuracy ranging from 3 to $10 \%$ means that the diagnostic system is capable of identifying the condition of tool wear with astounding precision, in the order of several micrometers. After adaptation of data acquisition system, the neural network-based diagnostic system may be used in practice, especially in machining of relatively homogenous material, such as MDF.

The next step focused on industrial application should be the optimization of factors measured during milling to become input data into neural network-based system. The analysis and choice of the proper neural network model should simplify the whole process and make it less complicated and expensive in practical application. 


\section{REFERENCES}

\section{LITERATURA}

1. Bratkowski, B.; Przydróżny, M., 2001: Sztuczne Sieci Neuronowe (Artificial Neural Networks) . Monografia Instytutu Sterowania i Systemów Informatycznych Politechniki Zielonogórskiej

(http://nrn.prv.pl, http://www.issi.uz.zgora.pl)

2. Byrne, G.; Dornfeld, D.; Inasaki, I.; Kettler, G.; Konig, W.; Teti, R., 1995: Tool Condition Monitoring (TCM) The statue of research and industrial application. Annals of CIRP, 44.

3. Chryssolouris, G.; Guillot, M. 1990: A comparison of statistical and AI approaches to the selection of process parameters in intelligent Machining. Journal of Engineering for Industry, 112.

4. Fischer, R., 1997: A way to observe and to calculate edge wearing in cutting wood-materials. Proceedings of the 13th International Wood Machining Seminar. Vancouver, Canada.

5. Gawlik, J.; Karbowski, K., 1997: Prognozowanie stanu ostrza skrawającego $\mathrm{z}$ zastosowaniem sieci neuronowych. Mechanik nr 4.

6. Kacalak, W, 1994: Zastosowania sieci neuronowych w budowie i eksploatacji maszyn. Mechanik nr 2.

7. Kozma, R.; Kitamura, M.; Sakuma, M.; Yokoyama, Y., 1994: Anomaly detection by neural network models and statistical time series analysis. IEEE International Conference on Neural Networks. Orlando, Florida, USA.

8. Li, X., 2001: Real Time Tool Wear Condition Monitoring in Turning. International Journal of Product Research, 39.

9. McKenzie, W.M.; Sheikh-Ahmad, J.Y., 1997: Measurement of tool wear and dulling in the machining of parti- cleboard. Proceedings of the 13th International Wood Machining Seminar. Vancouver, Canada.

10. Peklenik, J.; Jerele, A., 1992: Some basic relationships for identification of the machining process. Annals of CIRP 41, 155-159. doi:10.1016/S0007-8506(07)61174-3

11. Sick, B., 1997: On-line tool wear monitoring in Turning using Neural Networks. Badania Wydziału Matematyki I Nauk Komputerowych Uniwersytetu Passau, Niemcy.

12. Sick, B.; Sicheneder, A., 1998: Time delay neural networks for On-line Tool Wear Classification and Estimation in Turning. Badania Wydziału Matematyki I Nauk Komputerowych Uniwersytetu Passau, Niemcy.

13. Stein, J.L.; Huh, K., 1991: A design procedure for modelbased monitoring systems, cutting force estimation as a case study. Control o manufacturing processes. ASME Production Engineering Division Vol. 52.

14. Tadeusiewicz, R., 1992-2002: Sieci Neuronowe. Wydawnictwo Internetowe AGH.

15. Teshima, T.; Shibasaka,T.; Takuma, M., 1993: Estimation of cutting tool life by processing tool image data with neural network. Annals of CIRP No 42/1.

\section{Corresponding address:}

Assistant MARCIN ZBIEĆ, Ph.D.

Faculty of Wood Technology

Warsaw University of Life Sciences

Ul. Nowoursynowska 159

02-787 Warsaw, Poland

e-mail: marcin_zbiec@sggw.pl 